\title{
AN APPRAISAL OF THE ADEQUACY OF DIETARY MINERAL INTAKES IN DEVELOPING COUNTRIES FOR BONE GROWTH AND DEVELOPMENT IN CHILDREN
}

\author{
ANN PRENTICE AND CHRISTOPHER J. BATES \\ MRC Dunn Nutrition Unit, Cambridge, UK, and Keneba, The Gambia
}

\section{CONTENTS}

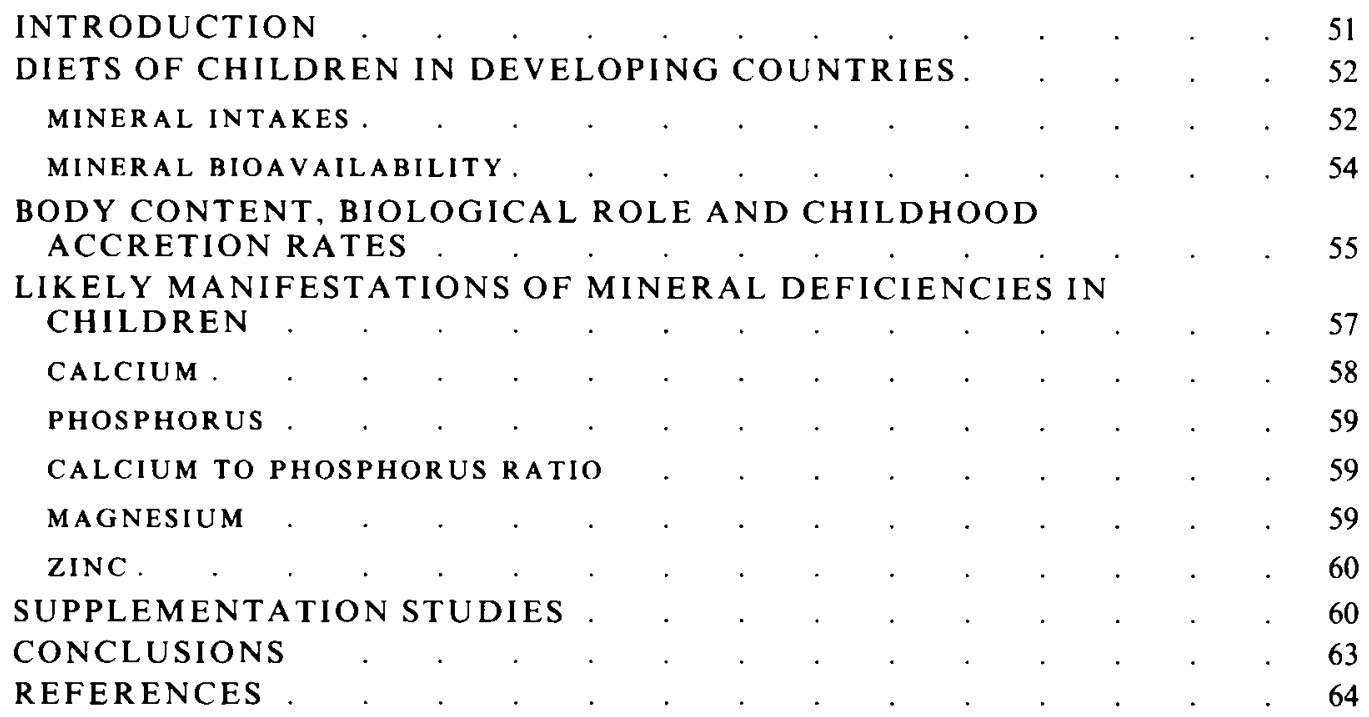

\section{INTRODUCTION}

Linear growth retardation in children, or stunting, is a major problem in the developing world. It has been estimated that the prevalence of stunting in children less than 5 years of age in Africa, the Americas and Asia (excluding China) is about $40 \%$, representing about 125 million individuals (Keller, 1988). Linear growth rates in developing countries begin to fall behind those in developed countries during the first two years of life and deficits in attained height remain throughout childhood (Waterlow, 1988). Inadequate nutrition, high morbidity rates, gastrointestinal dysfunction, poverty and related environmental factors may all play a role in the aetiology of stunting and in the prevention of complete catch-up growth after stunting has occurred (Keller, 1988).

The diets of impoverished people in the developing world are often monotonous and of poor quality. It has long been assumed that an inadequate provision of the four boneforming minerals, calcium, phosphorus, magnesium and zinc, due to low dietary intakes or to reduced bioavailability, could be an important contributory factor in the poor growth performance of children in the developing world. In this review we examine the evidence 
that stunting and other aspects of human bone development may be influenced by dietary mineral supply.

\section{DIETS OF CHILDREN IN DEVELOPING COUNTRIES}

\section{MINERAL INTAKES}

There is considerable variation in the diets consumed by disadvantaged peoples of the developing world but in many regions the main foodstuffs are cereals and other plant foods. In general, the consumption of meat and animal milks is limited (Bansal et al. 1964; Walker, 1972; Prentice, 1991 ; Prentice et al. 1993). As a consequence, Ca intakes by adults in these communities are low (Prentice et al. 1993). Intakes of $\mathrm{P}$ and $\mathrm{Mg}$, however, can be relatively high as cereals and plants are rich sources of both these minerals (Department of Health, 1991). Culinary practices, such as the use of plant ash (e.g. Nyasaland Bantu, Walker, 1954; American Indians \& Papua New Guineans, Golden, 1988), lime in the making of tortilla (Mexico, Cerqueira et al. 1979, Murphy et al. 1992), and dried baobab leaf in preparation of steamed millet (The Gambia, Prentice et al. 1993) may make valuable contributions to mineral intakes in some societies.

The diets of children in developing countries, however, may differ from those of adults. Many infants and toddlers are breast fed for prolonged periods and receive specially prepared weaning foods. Older children may receive preferential or reduced amounts of certain foods, such as milk or fish, relative to adults. Consequently, it is important to judge the adequacy of mineral supply during childhood by using dietary data collected from children. However, there have been comparatively few detailed investigations of mineral intakes of infants and children in the Third World. A selection of studies is summarized in Tables 1 and 2.

The data demonstrate that $\mathrm{Ca}$ intakes of children in many disadvantaged communities are very low. The figures in Table 1 can be compared with $\mathrm{Ca}$ intakes of British toddlers and older children which average $600-700 \mathrm{mg} / \mathrm{d}$ and $700-900 \mathrm{mg} / \mathrm{d}$ respectively (Department of Health, 1989; Prentice \& Paul, 1990). In contrast, the measured intakes of $\mathrm{Zn}$ are not dissimilar to those in affluent societies (Table 1; Sandstead, 1991), due to the fact that unrefined cereals and plant foods contain reasonably high amounts of $\mathrm{Zn}$ (Department of Health, 1991). The measured intakes of $P$ are moderate to high in older children, resulting in low $\mathrm{Ca}: \mathrm{P}$ ratios, $1: 2-1: 3$. Estimates of $\mathrm{P}$ intakes of young children in Western countries are $800-900 \mathrm{mg} / \mathrm{d}$ (Fomon, 1974). Children who are exclusively or partly breast fed have lower $P$ intakes and the $\mathrm{Ca}: \mathrm{P}$ ratio of their diet is higher (Table 2 , see below). In the limited number of studies in which $\mathrm{Mg}$ ingestion has been quantified, intakes of children in developing countries appear to be of the same order of magnitude as adult intakes in the UK (Department of Health, 1991).

Breast milk is a major dietary component for many infants and young children in the developing world. Breast milk production by mothers from disadvantaged communities is similar in general to that of mothers in affluent societies and is often maintained for long periods (Prentice et al. 1986). Mineral concentrations in mature breast milk decline as lactation progresses in women from both developed and developing countries (Bates \& Tsuchiya, 1990; Laskey et al. 1990, 1991). This is particularly striking for $\mathrm{Zn}$ (K rebs et al. 1985). There is little evidence of regional variations in $\mathrm{P}, \mathrm{Mg}$ and $\mathrm{Zn}$ concentrations in breast milk (Hambidge et al. 1986; Laskey et al. 1991) but low Ca concentrations have been reported from a number of developing countries and Gambian women have been shown to have $\mathrm{Ca}$ levels that are $20 \%$ below those of British women (Laskey et al. 1990). Whether this is a consequence of low maternal $\mathrm{Ca}$ intakes is not known. In general, average $\mathrm{Ca}, \mathrm{P}$, 
Table 1. Measured mineral intakes of children not receiving breast milk in developing countries

\begin{tabular}{|c|c|c|c|c|c|c|c|}
\hline Country & No. & Age & $\begin{array}{c}\mathrm{Ca} \\
(\mathrm{mg} / \mathrm{d})\end{array}$ & $\underset{(\mathrm{mg} / \mathrm{d})}{\mathbf{P}}$ & $\begin{array}{c}\mathrm{Mg} \\
(\mathrm{mg} / \mathrm{d})\end{array}$ & $\underset{(\mathrm{mg} / \mathrm{d})}{\mathrm{Zn}}$ & Reference \\
\hline Egypt & 15 & $13 y$ & 294 & 510 & . & - & Lawson et al. 1987 \\
\hline Egypt & 96 & $18-30 \mathrm{~m}$ & 218 & 624 & 203 & $5 \cdot 2$ & Murphy et al. 1992 \\
\hline India & 18 & $2 \cdot 5-5 y$ & 145 & 一 & - & - & Sundararaj et al. 1969 \\
\hline India & 45 & $2-6 y$ & 320 & 678 & - & - & Rajalakshmi et al. 1973 \\
\hline Kenya & 100 & $18-30 \mathrm{~m}$ & 210 & 556 & 241 & 3.7 & Murphy et al. 1992 \\
\hline Malawi & 66 & $4-6 y$ & 380 & - & - & $7 \cdot 0$ & Ferguson et al. 1989 \\
\hline Mexico & 59 & $18-30 \mathrm{~m}$ & $735^{\mathrm{a}}$ & 956 & 236 & $5 \cdot 4$ & Murphy et al. 1992 \\
\hline Papua & 27 & $3-7 y$ & 359 & - & - & $4 \cdot 6$ & Gibson et al. 1991 \\
\hline $\begin{array}{l}\text { New } \\
\text { Guinea }\end{array}$ & 40 & $8-10 y$ & 301 & - & - & $4 \cdot 3$ & \\
\hline $\begin{array}{l}\text { South } \\
\text { Africa }\end{array}$ & 6 & $7-12 y$ & 337 & 914 & - & - & Pettifor et al. 1979 \\
\hline Sri Lanka & - & $\begin{array}{l}5 y \\
10 y\end{array}$ & $\begin{array}{l}200 \\
400\end{array}$ & $\begin{array}{l}- \\
-\end{array}$ & - & - & $\begin{array}{l}\text { Nicholls \& } \\
\text { Nimalasuriya } 1939\end{array}$ \\
\hline
\end{tabular}

Mean values for boys and girls, seasons combined. ${ }^{\text {a }}$, High Ca associated with consumption of tortilla.

Table 2. Measured mineral intakes of breast fed children in developing countries

\begin{tabular}{lrcccccc}
\hline \hline Country & No. & Age & $\begin{array}{c}\text { Ca } \\
(\mathrm{mg} / \mathrm{d})\end{array}$ & $\begin{array}{c}\mathbf{P} \\
(\mathrm{mg} / \mathrm{d})\end{array}$ & $\begin{array}{c}\mathbf{M g} \\
(\mathrm{mg} / \mathrm{d})\end{array}$ & $\begin{array}{c}\mathrm{Zn} \\
(\mathrm{mg} / \mathrm{d})\end{array}$ & Reference \\
\hline India & 38 & $6 \mathrm{~m}-3 \mathrm{y}$ & 129 & 195 & & & Bansal et al. 1964 \\
Peru & 110 & $7-10 \mathrm{~m}$ & 376 & 407 & - & & Creèd de Kanashiro \\
& 100 & $10-13 \mathrm{~m}$ & 375 & 466 & - & - & et al. 1990 \\
Thailand & 85 & $1 \mathrm{y}$ & 143 & 237 & - & - & Chusilp et al. 1992 \\
& 85 & $2 \mathrm{y}$ & 118 & 335 & - & $\ldots$ & \\
The & 111 & $3 \mathrm{~m}$ & 181 & 141 & - & 1.7 & Prentice \& Paul $1990^{\mathrm{a}}$ \\
Gambia & 111 & $6 \mathrm{~m}$ & 196 & 186 & - & 1.9 & \\
& 101 & $9 \mathrm{~m}$ & 192 & 232 & $\ldots$ & 2.5 & \\
& 112 & $12-15 \mathrm{~m}$ & 214 & 324 & - & 3.5 & \\
& 99 & $15-18 \mathrm{~m}$ & 234 & 408 & - & 4.0 & \\
\hline \hline
\end{tabular}

Mean values for boys and girls, seasons combined, breast milk plus weaning foods. ${ }^{\mathrm{a}}$, Plus unpublished $\mathrm{Zn}$ data (A. Prentice, C. J. Bates \& A. A. Paul).

$\mathrm{Mg}$ and $\mathrm{Zn}$ intakes of exclusively breast fed children at 3 months are approximately $200 \mathrm{mg}, 100 \mathrm{mg}, 23 \mathrm{mg}$ and $1.8 \mathrm{mg}$ respectively, although there are wide variations in breast milk mineral outputs between individual mothers (Bates \& Tsuchiya, 1990; Laskey et al. 1990, 1991).

The contribution of breast milk to mineral intakes during partial breast feeding has been little studied. A detailed investigation in a poor rural village in The Gambia, where children are breast fed for about 2 years but receive weaning foods from 3 months, showed that breast milk still provides $40 \%, 20 \%$ and $15 \%$ of their $\mathrm{Ca}, \mathrm{P}$ and $\mathrm{Zn}$ intakes respectively at $15-18$ months of age (Table 3; Prentice \& Paul, 1990). In a Thai study, $58 \%$ of Ca intakes were provided by breast milk for children at 1 year (Chusilp et al. 1992). The value of the breast milk contribution may well be greater as mineral bioavailability is higher than from a mixed diet. However, the mineral density of breast milk is relatively low especially compared with animal milks and the weaning diet. For example, using Gambian data for 
Table 3. Contribution of breast milk to mineral intakes of rural Gambian childrent

\begin{tabular}{cccc}
\hline \hline Months of age & Ca & P & Zn \\
\hline 3 & 81 & 71 & 70 \\
6 & 62 & 52 & 52 \\
9 & 54 & 40 & 31 \\
$12-15$ & 50 & 29 & 23 \\
1518 & 40 & 20 & 15 \\
\hline \hline
\end{tabular}

+ Values are the percentage of total mineral intakes contributed by breast milk at each age. The calculations take no account of the differing bioavailability of minerals from breast milk and other foods.

Data are from Prentice \& Paul 1990; A. Prentice \& C. J. Bates (unpublished). Children in this community breast feed on demand for approximately two years, with weaning foods introduced from about 3 months of age. The local diet is based on rice, millet, groundnuts, fish and leaves (Prentice et al. 1993).

children over 12 months old, the mineral densities $(\mathrm{mg} / 100 \mathrm{kcal})$ for $\mathrm{Ca}, \mathrm{P}$ and $\mathrm{Zn}$ respectively in this community are $28,25,0.34$ for breast milk and $25,56,0.61$ for weaning foods while cows' milk has densities of $194,145,0.53$. Consequently, calculations indicate that, for these Gambian children, replacing breast milk with an isocaloric amount of other foods in their diet would not alter calcium intakes materially and would increase $\mathrm{P}$ and $\mathrm{Zn}$ intakes by $30 \%$ and $38 \%$ respectively (Prentice \& Paul 1990; A. Prentice, C. J. Bates \& A. A. Paul, unpublished). Similar data from other communities in the developing world are not available but the measured intakes of breast fed and not breast fed children (Tables 1 and 2) suggest that a similar pattern would be expected in other areas. Breast milk, therefore, although making substantial contributions to the intakes of many children in the developing world, is not an especially rich source of these minerals.

\section{MINERAL BIOAVAILABILITY}

In general, only $30-40 \%$ of dietary $\mathrm{Ca}$ and $\mathrm{Zn}$ are absorbed from typical Western diets, while absorption of $\mathrm{P}$ and $\mathrm{Mg}$ is somewhat higher at $40-60 \%$ (Schwartz, 1990; Department of Health, 1991). Ca absorption from predominantly plant based diets is thought to be considerably reduced due to the chelation properties of compounds such as phytates (inositol hexaphosphates) and oxalates (Allen, 1982). The Ca: $\mathrm{P}$ ratio, per se, appears to be relatively unimportant (Department of Health, 1991) except that in developing countries a low $\mathrm{Ca}: \mathrm{P}$ ratio is likely to imply a high phytate intake. $\mathrm{Zn}$ absorption also appears to be affected by phytate, dietary fibre and by geophagia (King \& Turnlund 1988; Prasad, 1991). An important consideration in $\mathrm{Zn}$ bioavailability is thought to be the phytate and $\mathrm{Ca}$ content of the diet, with a high $\mathrm{Ca} \times$ phytate product being associated with increased formation of insoluble complexes (Bindra et al. 1986; Sandstead, 1991; Xu et al. 1992).

A number of studies, however, have suggested that in practice the long term effects of food phytates on Ca absorption may not be large (Walker et al. 1948; Walker, 1951; Bronner et al. 1954, 1956; Irving, 1964; Bhaskaram \& Reddy, 1979) and there is controversy over the effect of phytates on $\mathrm{Zn}$ absorption (Anderson et al. 1981; Hambidge et al. 1986). Hydrolysis of phytate may occur in the human intestine (Xu et al. 1992) and phytate $\mathrm{P}$ is well absorbed particularly when Ca intakes are low (Walker et al. 1948; Irving, 1964). In addition, methods of food preparation may significantly diminish the effects of phytate, such as the action of phytases during baking, fermentation and germination (Irving, 1964; Golden, 1988; Murphy et al. 1992). Other components of the diet can increase or reduce mineral bioavailability by altering absorption or excretion, for example protein, fat, salt and other minerals (Allen, 1982; Department of Health, 1991) and high 
intakes of non-haem iron have been shown to depress $\mathrm{Zn}$ absorption (Solomons \& Jacob, 1981; Hambidge et al. 1986). In addition, gastrointestinal illnesses, common in children in many developing countries, can have deleterious effects on mineral absorption.

The extent to which individuals habituated to low mineral intakes have adapted to their diets is unknown. Positive balances have been reported in children and adults with low $\mathrm{Ca}$ and $\mathrm{Zn}$ intakes (Hegsted et al. 1952; Luyken \& Luyken-Koning, 1961; Begum \& Pereira, 1969 ; Ziegler et al. 1989), indicating that absorption efficiency must be high and losses low. It has been suggested that colonic absorption, after degradation of fibre and phytate by bacteria, may play an important role in this context (Sandström et al. 1986; Fraser, 1988a, 1991). Adaptation of Ca metabolism to diets containing high amounts of phytate has been observed (Walker et al. 1948). Mg and $\mathrm{Zn}$ restrictions are also accompanied by increases in absorption efficiencies and decreases in endogenous losses (Widdowson \& Dickerson, 1964; Schwartz, 1990; Department of Health, 1991; Taylor et al. 1991).

\section{BODY CONTENT, BIOLOGICAL ROLE AND CHILDHOOD ACCRETION RATES}

The question of whether the dietary intakes of children in developing countries are sufficient to support optimal bone growth and development has to be discussed in relation to the mineral requirements of the human body during childhood. Table 4 provides details of the body content of $\mathrm{Ca}, \mathrm{P}, \mathrm{Mg}$ and $\mathrm{Zn}$ in a newborn baby born at term, a typical man and a typical woman. As can be seen, an adult contains approximately $1 \mathrm{~kg}$ and $0.5 \mathrm{~kg}$ of $\mathrm{Ca}$ and $\mathrm{P}$ respectively, while $\mathrm{Mg}$ and $\mathrm{Zn}$ are present in smaller quantities.

The body compartments of the four minerals are summarized in Table 4. Approximately $99 \%$ of $\mathrm{Ca}$ and $80 \%$ of $\mathrm{P}$ in the body are contained in the inorganic phase of bone and teeth, imparting structure and strength. The crystal structure of bone salt resembles hydroxyapatite $\left[\mathrm{Ca}_{10}\left(\mathrm{PO}_{4}\right)_{6}(\mathrm{OH})_{2}\right]$, which contains $\mathrm{Ca}$ and $\mathrm{P}$ in the proportion $2 \cdot 15: 1$ (by mass) (Russell et al. 1986). However, crystallization of bone salt occurs in several stages, proceeding from amorphous calcium phosphate through intermediate crystalline structures (Russell et al. 1986). These compounds have lower $\mathrm{Ca}: \mathbf{P}$ ratios by weight than hydroxyapatite and consequently the proportion of $\mathrm{Ca}$ to $\mathrm{P}$ in young bone is generally between $1 \cdot 7: 1$ and $2 \cdot 14: 1$ (Specker \& Tsang, 1987). The measured mass ratio in adult human bone ash is about 2.3:1 (Mitchell et al. 1945).

Bone salt is not pure hydroxyapatite, since it contains anions such as carbonate and citrate, and cations such as $\mathrm{Mg}$ and $\mathrm{Sn}$ (Widdowson \& Dickerson, 1964). These ions either substitute within the crystal lattice or are adsorbed onto the crystal surface (Russell et al. 1986). Approximately $60 \%$ of body $\mathrm{Mg}$ and $30 \%$ of body $\mathrm{Zn}$ are present in the skeleton where their concentrations are higher than in other tissues in the body (Schwartz, 1990; Department of Health, 1991). $\mathrm{Zn}$ is associated with alkaline phosphatase at calcification sites and is also deposited within the inorganic matrix (Hambidge et al. 1986). The function of $\mathrm{Mg}$ and $\mathrm{Zn}$ in bone is largely unknown. $\mathrm{Mg}$ may play a role in the control of crystal formation and in crystal stability (Schwartz, 1990) while $\mathrm{Zn}$ is thought to be involved in chondrogenesis, collagen synthesis, osteoblastic function and calcification (Hambidge $e t a l$. 1986).

All four minerals have important functions outside the bone compartment and are widely distributed throughout the soft tissues and fluids (Department of Health, 1991). The remaining $1 \%$ of total body $\mathrm{Ca}$ is involved in processes such as nerve and muscle function, blood clotting and intracellular signalling. Non-osseous $\mathbf{P}$ is a component of many essential compounds, such as phospholipids and those with high energy phosphate bonds like ATP. Non-skeletal Mg is involved in DNA replication, RNA synthesis, and is a cofactor 
Table 4. Whole body mineral content and compartments of calcium, phosphorus, magnesium and zinc in $\operatorname{man}^{a}$

\begin{tabular}{lccccc}
\hline \hline & & \multicolumn{2}{c}{ Adult } & \multicolumn{2}{c}{ Body compartment } \\
\cline { 3 - 6 } & $\begin{array}{c}\text { Baby" } \\
(\mathrm{gm})\end{array}$ & $\begin{array}{c}\text { Male }^{\mathrm{c}} \\
(\mathrm{gm})\end{array}$ & $\begin{array}{c}\text { Female }^{\mathbf{d}} \\
(\mathrm{gm})\end{array}$ & $\begin{array}{c}\text { Bones } \\
(\%)\end{array}$ & $\begin{array}{c}\text { Soft tissues } \\
(\%)\end{array}$ \\
\hline Calcium & 28.2 & 1344 & 1008 & 99 & 1 \\
Phosphorus & 16.2 & 720 & 540 & 80 & 20 \\
Magnesium & 0.76 & 28.2 & 21.2 & 60 & 40 \\
Zinc & 0.053 & 1.68 & 1.26 & 30 & 70 \\
\hline \hline
\end{tabular}

To convert $\mathrm{mg}$ to $\mathrm{mmol}$ divide by $40,31,24 \cdot 3,65 \cdot 4$ for $\mathrm{Ca}, \mathrm{P}, \mathrm{Mg}, \mathrm{Zn}$ respectively.

a Chemical data from Widdowson \& Dickerson (1964).

b Based on $3.5 \mathrm{~kg}$ full-term infant.

c Based on $60 \mathrm{~kg}$ fat-free mass (e.g. man $70 \mathrm{~kg}$ body weight, $15 \%$ fat).

d Based on $45 \mathrm{~kg}$ fat-free mass (e.g. woman $60 \mathrm{~kg}$ body weight, $25 \%$ fat).

Table 5. Estimated mineral accretion rates in childhood

\begin{tabular}{llccccc}
\hline \hline & \multicolumn{2}{c}{ Continuous $^{\mathrm{a}}$} & \multicolumn{2}{c}{ Infancy $^{\mathrm{b}}$} & \\
\cline { 2 - 5 } & Male & Female & $0-4 \mathrm{~m}$ & $4-12 \mathrm{~m}$ & \multirow{2}{*}{ Peak $^{\mathrm{c}}$} \\
\hline Calcium, mg/d & 200 & 149 & 155 & 130 & 400 \\
Phosphorus, mg/d & 107 & 80 & 79 & 66 & 214 \\
Magnesium, mg/d & 4.2 & 3.1 & 3.3 & 2.7 & 8.4 \\
Zinc, mg/d & 0.25 & 0.18 & 0.5 & 0.3 & 0.5 \\
\hline \hline
\end{tabular}

a Average accretion rate in childhood based on assumption of continuous growth and maturity at eighteen years in both sexes (British Nutrition Foundation, 1989).

b Accretion in infancy as calculated by Fomon (1974), Krebs \& Hambidge (1986).

' Peak rate in adolescence based on calcium calculation of Kanis \& Passmore (1989) and assuming proportions of $\mathrm{Ca}, \mathrm{P}, \mathrm{Mg}, \mathrm{Zn}$ are the same as during continuous growth.

for enzymes requiring ATP. $\mathrm{Zn}$ is essential for cell division, nucleic acid and protein synthesis, and is a component of many enzymes. Unlike the other three minerals, the major portion of total body $\mathrm{Zn}$ occurs not in bone but in the soft tissues, primarily in muscle (Table 4), although the concentration of $\mathrm{Zn}$ in bone is high.

Considerable quantities of all four minerals are deposited in the body between birth and maturity. The accretion of mineral is greater than the increase in body weight over the same period. For example, the amount of $\mathrm{Ca}$ expressed relative to body weight increases from approximately $8 \mathrm{~g} \mathrm{Ca} / \mathrm{kg}$ at birth to $19 \mathrm{~g} \mathrm{Ca} / \mathrm{kg}$ in a $70 \mathrm{~kg}$ man (Table 4; Widdowson \& Dickerson, 1964). Table 5 gives estimated values, based largely on the compositional data in Table 4, for mineral accretion rates during childhood. The continuous rates have been obtained by assuming that maturity is reached by 18 years of age in both sexes and that the accretion rate is constant throughout childhood (after British Nutrition Foundation, 1989). Such calculations indicate, for example, that a boy who at maturity has a fat-free mass of $60 \mathrm{~kg}$ (equivalent to a $70 \mathrm{~kg}$ man with $15 \%$ body fat) has to retain $200 \mathrm{mg} \mathrm{Ca}, 107 \mathrm{mg} \mathrm{P}$, $4 \mathrm{mg} \mathrm{Mg}$ and $0.25 \mathrm{mg} \mathrm{Zn}$ every day for eighteen years in order to achieve the required mineral deposition (Table 5). In reality, of course, growth is not uniform and is greatest soon after birth and during adolescence. At these times accretion rates will be considerably higher than average, while rates will be somewhat less in the intervening years. In addition, 
mineral deposition during periods of catch-up growth, when children are recovering from illness or malnutrition, will be substantially above average. Estimates of likely accretion rates in infancy and in adolescence are given in Table 5, based on the arguments of Kanis \& Passmore (1989), British Nutrition Foundation (1989), Fomon (1974), and Leitch \& Aitken (1959). The values in infancy for $\mathrm{Ca}, \mathrm{P}, \mathrm{Mg}$ are somewhat lower than the continuous accretion rates due to the relatively low mineral content of young bone (Fomon, 1974).

In addition to the requirements for growth, losses of the four minerals occur in urine, sweat, gastrointestinal fluids, skin, hair and nails. Quantitative data on mineral losses in infants and children are very limited. There is evidence, however, that mineral losses are greatly reduced in individuals habituated to very low intakes (Nicholls \& Nimalasuriya, 1939; Widdowson \& Dickerson, 1964; Begum \& Pereira, 1969; Taylor et al. 1991) and it is unclear what figures should be used as estimates of obligatory losses. The British Committee for Medical Aspects of Food Policy (COMA) in their recent evaluation of dietary reference values assumed that there are no obligatory $\mathrm{Ca}$ losses in children and gave no figures for $\mathrm{P}$ or $\mathrm{Mg}$ (Department of Health, 1991). Daily endogenous $\mathrm{Zn}$ losses in infants have been estimated at $0.07 \mathrm{mg} / \mathrm{kg}$ (Ziegler et al. 1989) in faeces and $0.02 \mathrm{mg} / \mathrm{kg}$ in urine and sweat (Krebs \& Hambidge, 1986), producing a total estimated requirement for accretion + losses of 0.9-1.2 mg/d (King \& Turnlund, 1988; Department of Health 1991).

The number of studies on the composition of the human body is very limited, involving the chemical analyses of only a small number of possibly atypical individuals (Widdowson \& Dickerson, 1964; British Nutrition Foundation, 1989). In addition, differences in chemical composition may exist between the races, for example adult Blacks in the United States are known to have higher total body $\mathrm{Ca}$ and $\mathrm{P}$ content than Whites of the same height (Cohn et al. 1977). The figures in Tables 4 and 5, therefore, can be used to provide only an approximate assessment of mineral deposition during childhood. Similarly, the data on endogenous losses in children are uncertain and there are likely to be considerable variations between individuals. However, these data provide a useful basis on which to discuss the likely adequacy of dietary supply for children in Third World countries and for this purpose the following figures, based on the continuous accretion rate for body (Table 5) + losses for $\mathrm{Zn}$, are a useful rough guide: $\mathrm{Ca} 200 \mathrm{mg} / \mathrm{d}, \mathrm{P} 100 \mathrm{mg} / \mathrm{d}, \mathrm{Mg} 4 \mathrm{mg} / \mathrm{d}, \mathrm{Zn}$ $1 \mathrm{mg} / \mathrm{d}$. These figures will be referred to in the rest of the text as the 'biological requirement'.

A comparison of measured intakes (Tables 1 and 2) with theoretical deposition rates (Table 5) demonstrates that the $\mathrm{Ca}$ intakes of many children in developing countries are very close to the biological requirement. This is before allowing for losses in body fluids, for incomplete absorption or for illness. Measured $\mathbf{P}$ and $\mathrm{Zn}$ intakes of children who are no longer breast fed are substantially greater than theoretical accretion rates (approximately 5-10 times). However, $\mathrm{Zn}$ supply may approach the biological requirement when losses and absorption are considered (Hambidge et al. 1986; Department of Health, 1991). The Zn, and to some extent the $P$, intakes during breast feeding are close to the biological requirement particularly in older children receiving little supplementary food (Sandstead, 1985; Krebs \& Hambidge, 1986). $\mathrm{Mg}$ intakes are considerably higher than theoretical accretion rates at all ages (approximately $10-50$ times).

\section{LIKELY MANIFESTATIONS OF MINERAL DEFICIENCIES IN CHILDREN}

Is there any evidence to indicate that children in developing countries have problems which could be attributed specifically to mineral deficiencies? It is well known that severe protein-energy malnutrition in children results in linear growth retardation and reduced 
bone mineral contents which resemble juvenile osteoporosis (Garn et al. 1964; Adams \& Berridge, 1969) and that skeletal maturation, as assessed by the appearance of ossification centres, is sometimes delayed (Adams \& Berridge, 1969). In contrast, very little is known about the manifestations of specific deficiencies of bone-forming minerals in the human. As all the $\mathrm{Ca}$ and $\mathrm{P}$ needed for building bones must originate from the diet, and as there are no significant extraskeletal reservoirs of these minerals, there must be intakes which cannot support normal growth and bone development.

\section{CALCIUM}

There is evidence to suggest that very low $\mathrm{Ca}$ intakes in children may result in rickets and osteomalacia (Pettifor, 1991). This is based on a number of case reports from the United States and South Africa of infants and children presenting with radiological rickets, growth retardation and biochemical signs of hyperparathyroidism but with normal vitamin D status (Maltz et al. 1970; Kooh et al. 1977; Pettifor et al. 1978, 1981 a; Pettifor, 1991). The previous diets of these children were very low in $\mathrm{Ca}$ and all the children responded to $\mathrm{Ca}$ rich hospital diets. Iliac crest biopsies from some of the South African children revealed osteopenia (undermineralization) as characterized by a reduced amount of calcified trabecular bone, severe osteomalacia as evidenced by increased osteoid volume, surface and thickness, a reduced calcification front and a prolonged mineralization lag time, and lesions suggestive of hyperparathyroidism such as increased numbers of osteoblasts and enhanced osteoclastic bone resorption (Marie et al. 1982; Pettifor, 1991). The mechanism by which Ca deficiency may cause rickets is unknown but may involve increased catabolism of 25hydroxy vitamin D in the liver (Clements et al. 1987; Fraser, 1988 b).

The human evidence has similarities to results obtained in experiments with young vitamin $\mathrm{D}$ replete baboons fed diets low in $\mathrm{Ca}$ but adequate in $\mathrm{P}$ for $8-16$ months. Mild radiological rickets and histological features of osteomalacia, such as increases in growth plate thickness, osteoid seam thickness, volume and surface, delays in calcification rate and increases in mineralization time (Pettifor et al. 1984) were observed. Biochemical abnormalities suggestive of hyperparathyroidism, such as a transient fall in serum Ca and raised alkaline phosphatase levels, also developed. However, similar experiments with juvenile cinnamon ringtail monkeys produced no radiological, biochemical or histological effects of a low $\mathrm{Ca}$ diet adequate in $\mathrm{P}$ over a 7 year period (Anderson et al. 1977). The observations in children and baboons are in contrast to the situation with growing laboratory animals. In rats calcium deficiency leads to osteoporosis with no impairment of linear growth until the bone mineral content is less than $50 \%$ of normal (Moore et al. 1963; Fraser, $1988 a$ ) while young mice appear to be relatively insensitive to low Ca diets (Ornoy et al. 1974).

The effects of marginally low $\mathrm{Ca}$ intakes in children are difficult to assess. Studies in South African village children showed that a significant number of individuals had biochemical signs of hyperparathyroidism (low serum $\mathrm{Ca}$, raised alkaline phosphatase) (Pettifor et al. 1979; Eyberg et al. 1986) which normalized after calcium supplementation (Pettifor et al. 1981 b, see later). Raised alkaline phosphatase levels have also been observed in underprivileged Brazilian children (Linhares et al. 1986). South African children aged 8-16 years with low $\mathrm{Ca}$ intakes and low serum $\mathrm{Ca}$ levels have reduced forearm bone densities and metacarpal cortical thickness compared with other children in the community of the same age, weight and height (Eyberg et al. 1986). Low forearm bone mineral contents relative to body size have also been noted in Gambian children (Lo et al. 1990; Prentice et al. 1990). However, chemical analysis of skeletons from children and adults in Ceylon 
revealed no marked differences in the amount of Ca per unit dry weight of bone (Nicholls \& Nimalasuriya, 1939) and no indications that low Ca intakes were associated with bone rarefaction or reduced compact bone width were noted in X-rays of children in Surinam (Luyken \& Luyken-Koning, 1969). Rickets, however, is a common problem in many tropical countries and in children consuming macrobiotic diets in Western countries and it has been speculated that low calcium intakes may be a predisposing factor (Dagnelie et al. 1990; Fraser, 1991).

\section{PHOSPHORUS}

There is evidence that phosphorus deficiency, like calcium, precipitates rickets in children: the rickets-like metabolic bone disease of premature babies is currently believed to be primarily a problem of phosphorus supply (Bishop, 1989; Pettifor, 1991). It is characterized by hypophosphataemia, raised serum alkaline phosphatase levels, low urinary phosphorus excretion and a reduced ability to retain $\mathrm{Ca}$ as shown by hypercalciuria. The disorder can be ameliorated largely by phosphate supplementation (Bishop, 1989; Pettifor, 1991).

Marginal $P$ intakes have been implicated in the incidence of bladder stones in young children of Northeast Thailand (Valyasevi et al. 1969). Infants and children living in a stone endemic area excrete low levels of $\mathbf{P}$ and high amounts of $\mathrm{Ca}$ in their urine and crystalluria is common (Valyasevi \& Dhanamitta, 1967; Valyasevi et al. 1967, 1969), features which were ameliorated with phosphate supplementation (Valyasevi et al. 1969). Breast milk contains relatively low amounts of $\mathrm{P}$, with a $\mathrm{Ca}: \mathrm{P}$ ratio of approximately $2: 1$. Phosphate supplementation of breast fed children during the first two weeks of life has been shown to enhance $\mathrm{Ca}, \mathrm{P}$ and $\mathrm{Mg}$ retentions (Widdowson et al. 1963). However, prior to the development of modern formula milks, excessive phosphorus intakes by neonates given feeds based on unmodified cows' milk were associated with hyperphosphataemia, hypocalcaemia and tetany (Oppé \& Redstone, 1968).

\section{CALCIUM TO PHOSPHORUS RATIO}

It is possible that the effects of $\mathrm{Ca}$ and $\mathrm{P}$ deficiencies may arise from an imbalance of the two bone-forming minerals in the diet despite the fact that in adults the $\mathrm{Ca}: \mathrm{P}$ ratio appears to have little influence on $\mathrm{Ca}$ absorption (see earlier). The children with rickets in the United States and South Africa had diets low in Ca but adequate or high in P (Maltz et al. 1970; Kooh et al. 1977; Pettifor, 1981 a). Diets containing low ratios of $\mathrm{Ca}: \mathrm{P}$ are known to produce secondary hyperparathyroidism in young horses, dogs and other animals (Marie et al. 1982; Fraser, 1988a). Young baboons fed diets low in Ca and P for 8-16 months did not exhibit the histological or biochemical abnormalities that were observed in animals fed diets low in Ca but adequate in P (Pettifor et al. 1984). However, studies in young ringtail monkeys showed that altering the $\mathrm{Ca}: \mathrm{P}$ ratio in the range $1: 4$ to $1: 0 \cdot 4$ had no consequences (Anderson et al. 1977).

\section{MAGNESIUM}

Severe magnesium deficiency in man is characterized by muscle weakness, neuromuscular dysfunction and cardiac disturbances (Department of Health, 1991), normally in association with debilitating diseases such as diabetes and alcoholism (Wacker \& Vallee, 1964; Department of Health, 1991). Failure to thrive, growth retardation, bone abnormalities and disturbances of Ca metabolism have been described in $\mathrm{Mg}$ depleted animals (Schwartz, 1990; Department of Health, 1991). The Mg content in bone of growing 
$\mathrm{Mg}$ deficient animals can be $80 \%$ below normal although calcium contents are often increased (Schwartz, 1990).

\section{ZINC}

In contrast to $\mathrm{Ca}, \mathrm{P}$ and $\mathrm{Mg}$, the consequences of human $\mathrm{Zn}$ deficiency have been well documented due to problems arising from acrodermatitis enteropathica (an inherited disorder affecting $\mathrm{Zn}$ absorption), sickle-cell anaemia, chronic renal disease and other conditions (Aggett, 1988). Moderate to severe $\mathrm{Zn}$ deficiency in children depresses growth, appetite, skeletal maturation and gonad development which can be reversed with $\mathrm{Zn}$ treatment (Aggett, 1988; Prasad, 1991). Zn deficiency is associated with metabolic disturbances of a wide range of hormones, cytokines and enzymes involved in growth and bone development (e.g. IGF-1 (somatomedin C), growth hormone, thyroid hormone, insulin, prolactin, alkaline phosphatase and prostaglandins) (Hambidge et al. 1986). In addition, $\mathrm{Zn}$ deficiency affects the immune system, the structure of the skin and intestinal mucosa, taste perception, wound healing, and dark adaptation (Hambidge et al. 1986; Aggett, 1988; O’Dell \& Reeves, 1988; Department of Health, 1991; Prasad, 1991). Children with severe malnutrition show clinical signs and immunological deficits which are correctable by $\mathrm{Zn}$ (Golden et al. 1978; Golden \& Golden, 1979; see later). Whether the effects of $\mathrm{Zn}$ deficiency on growth and bone development are a direct consequence of inadequate $\mathrm{Zn}$ supply for bone formation or are secondary to the effects of $\mathrm{Zn}$ on appetite, the action of growth promoting factors or cell division is not known (Leek et al. 1988).

Marginal $\mathrm{Zn}$ deficiency in rhesus monkeys during gestation and postnatal life has been shown to cause growth retardation, delayed skeletal maturation and defective mineralization (Golub et al. 1984; Leek et al. 1984, 1988). The bone abnormalities, which were most severe at 6 months of age and gradually improved thereafter, were similar to those seen in human rickets (Leek et al. 1984, 1988).

A number of observations suggest that $\mathrm{Zn}$ deprivation may be implicated in human growth retardation. Adolescent nutritional dwarfism in Middle East countries, characterized by poor growth and delayed sexual maturity, has been related to $\mathrm{Zn}$ deficiency in association with deficiencies of other nutrients (Prasad, 1991). In addition, poor Zn status, as suggested by low $\mathrm{Zn}$ levels in blood or hair, has been described in growth-retarded Chinese, Mexican, Thai and Papua New Guinean children among others (Chase et al. 1980; Chen et al. 1985; Udomkesmalee et al. 1990; Gibson et al. 1991).

\section{SUPPLEMENTATION STUDIES}

Ultimately the test of whether specific mineral deficiencies may affect the growth and bone development of children in the developing world can only be answered by carefully controlled supplementation studies. To date there have been relatively few such investigations and most have involved supplementation with either $\mathrm{Zn}$ or $\mathrm{Ca}$. Those studies in which growth has been used as an outcome indicator are summarized in Tables 6-8. $\mathrm{Zn}$ supplementation studies of Western children have been included in Table 6 because of the similarity of their $\mathrm{Zn}$ intakes to those of Third World children.

It is difficult to generalize the results of the supplementation studies because of wide differences in treatments used, subject ages, social class and home diet, and because many of the investigations, although controlled, were not randomized or double-blind. Despite this, the accumulating evidence suggests that $\mathrm{Zn}$ supplementation can increase the height and weight gains of certain groups, particularly infant and adolescent boys, in both developed and developing countries. The response may be limited to individuals with 
Table 6. Controlled Zn supplementation studies of well children

\begin{tabular}{|c|c|c|c|c|c|c|c|c|}
\hline & Subjects $^{\mathbf{a}}$ & Age & Number & $\begin{array}{c}\text { Zinc } \\
\text { dose } \\
(\mathrm{mg} / \mathrm{d})\end{array}$ & $\begin{array}{l}\text { Suppl. } \\
\text { time } \\
\text { (months) }\end{array}$ & Outcome & & Reference \\
\hline Australia & GR & $5-15 y$ & $173(\mathrm{M}+\mathrm{F})$ & $9-18$ & 10 & Height & 0 & 1 \\
\hline Aborigines & Low SE & & & & & Weight & 0 & \\
\hline Canada & $\begin{array}{l}\text { GR } \\
\text { Mid SE }\end{array}$ & $5-7 y$ & $60 \mathrm{M}$ & 10 & 12 & $\begin{array}{l}\text { Height all } \\
\text { Height low } \mathrm{Zn}^{\mathrm{b}}\end{array}$ & $\begin{array}{l}0 \\
+\end{array}$ & 2 \\
\hline Ecuador & $\begin{array}{l}\text { GR } \\
\text { Low SE }\end{array}$ & $12-48 m$ & $119(\mathrm{M}+\mathrm{F})$ & 10 & 15 & $\begin{array}{l}\text { Length } \\
\text { Weight }\end{array}$ & $\begin{array}{l}+ \\
0\end{array}$ & 3 \\
\hline Egypt & GR & $11-18 y$ & $279 \mathrm{M}$ & 12 & $5 \cdot 5$ & $\begin{array}{l}\text { Height } \\
\text { Bone age } \\
\text { Sex maturity }\end{array}$ & $\begin{array}{l}0 \\
0 \\
0\end{array}$ & 4 \\
\hline $\begin{array}{l}\text { France } \\
\text { Immigrants }\end{array}$ & $\begin{array}{l}\text { BF' } \\
\text { Low SE }\end{array}$ & $4-9 \mathrm{~m}$ & $57(M+F)$ & 5 & 3 & $\begin{array}{l}\text { Length (M) } \\
\text { Length (F) } \\
\text { Weight }\end{array}$ & $\begin{array}{l}+ \\
0 \\
0\end{array}$ & 5 \\
\hline $\operatorname{Iran}^{\mathrm{d}}$ & $\begin{array}{l}\text { GR } \\
\text { Suppl." }\end{array}$ & $12-14 y$ & $60 \mathrm{M}$ & 28 & 7 & $\begin{array}{l}\text { Height } \\
\text { Weight } \\
\text { Bone }^{r} \\
\text { Sex maturity }\end{array}$ & $\begin{array}{l}+ \\
+ \\
0 \\
+\end{array}$ & 6 \\
\hline Iran & $\begin{array}{l}\text { GR } \\
\text { Suppl." }\end{array}$ & $13 y$ & $\begin{array}{l}49 \mathrm{M} \\
11 \mathrm{~S}, 11 \mathrm{Zn}\end{array}$ & 40 & 18 & $\begin{array}{l}\text { Height } \\
\text { Weight } \\
\text { Bone age } \\
\text { Sex maturity }\end{array}$ & $\begin{array}{l}+ \\
+ \\
+ \\
0\end{array}$ & 7 \\
\hline $\begin{array}{l}\text { The } \\
\text { Gambia }\end{array}$ & $\begin{array}{l}\text { GR } \\
\text { Low SE }\end{array}$ & $7-27 \mathrm{~m}$ & $110(M+F)$ & 14 & 15 & $\begin{array}{l}\text { Length } \\
\text { Weight } \\
\text { MUAC }\end{array}$ & $\begin{array}{l}0 \\
0 \\
+\end{array}$ & 8 \\
\hline USA & $\begin{array}{l}\mathrm{FF}^{\mathrm{h}} \\
\text { Normal }\end{array}$ & Birth & $34 \mathrm{M}, 34 \mathrm{~F}$ & $5 \cdot 8^{i}$ & 6 & $\begin{array}{l}\text { Length (M) } \\
\text { Length (F) } \\
\text { Weight (M) } \\
\text { Weight (F) }\end{array}$ & $\begin{array}{l}+ \\
0 \\
+ \\
0\end{array}$ & 9 \\
\hline USA & $\begin{array}{l}\text { Normal } \\
\text { Mid SE }\end{array}$ & $33-90 \mathrm{~m}$ & $96(M+F)$ & $2 \cdot 6$ & 9 & $\begin{array}{l}\text { Length } \\
\text { Weight } \\
\text { Diet }\end{array}$ & $\begin{array}{l}0 \\
0 \\
0\end{array}$ & 10 \\
\hline USA & $\begin{array}{l}\text { GRt } \\
\text { Low SE }\end{array}$ & $26 y$ & $26 \mathrm{M}, 14 \mathrm{~F}$ & 5 & 12 & $\begin{array}{l}\text { Length }(M) \\
\text { Length }(F)\end{array}$ & $\begin{array}{l}+ \\
0\end{array}$ & 11 \\
\hline USA & $\begin{array}{l}\text { GR† } \\
\text { Low SE }\end{array}$ & $26 y$ & $10 \mathrm{M}, 5 \mathrm{~F}$ & 5 & 12 & $\begin{array}{l}\text { Diet (M) } \\
\operatorname{Diet}(\mathrm{F})\end{array}$ & $\begin{array}{l}+ \\
0\end{array}$ & 12 \\
\hline USA $^{j}$ & $\begin{array}{l}\text { GR } \\
\text { Low SE }\end{array}$ & $8-27 \mathrm{~m}$ & $26 \mathrm{M}, 24 \mathrm{~F}$ & $5 \cdot 7$ & 6 & $\begin{array}{l}\text { Length } \\
\text { Weight }\end{array}$ & $\begin{array}{l}0 \\
+\end{array}$ & 13 \\
\hline
\end{tabular}

Unless stated all children continued with their normal diet during study. M, male; F, female; S, supplement, no extra zinc; $\mathrm{Zn}$, supplement plus extra $\mathrm{Zn}$; MUAC, mid upper arm circumference; Diet, dietary intake; + significant effect of supplement; 0 , no effect.

Subjects: GR, growth retarded; SE, socioeconomic class; †. low plasma/hair Zn.

Dubjects with hair $\mathrm{Zn}<1.68 \mu \mathrm{mol} / \mathrm{g}$.

c BF, breast fed (+ undescribed weaning foods).

a Children with heights below the 3 rd centile.

e Protein, vitamin and micronutrient supplement with and without added $\mathrm{Zn}$.

' Bone, length, width, medullary width of second metacarpal.

L Liquid protein and vitamin supplement with and without added $\mathrm{Zn}$.

h FF, formula fed (Similac +iron (a) $1.8 \mathrm{mg} \mathrm{Zn/l).}$

i $5.8 \mathrm{mg} / \mathbf{l}$ formula milk.

${ }^{j}$ Children with failure to thrive.

References are:

1. Smith et al. 1985, 2. Gibson et al. 1989, 3. Dirren et al. 1993, 4. Carter et al. 1969, 5, Walravens et al. 1992. 6. Ronaghy et al. 1969, 7. Ronaghy et al. 1974, 8. Bates et al. 1993, 9. Walravens \& Hambidge 1976, 10. Hambidge et al. 1979, 11. Walravens et al. 1983, 12. Krebs et al. 1984, 13. Walravens et al. 1989. 
Table 7. Zinc supplementation studies of severely malnourished children

\begin{tabular}{|c|c|c|c|c|c|c|c|c|}
\hline & & Age & Number & $\begin{array}{c}\text { Daily } \\
\text { zinc } \\
\text { dose } \\
(\mathrm{mg} / \mathrm{kg})^{\mathrm{a}}\end{array}$ & $\begin{array}{c}\text { Suppl. } \\
\text { length } \\
\text { (months) }\end{array}$ & Outcome & & Reference \\
\hline Bangladesh & Mal & $1-7 y$ & $25(M+F)$ & 50 & 0.5 & $\begin{array}{l}\text { Weight } \\
\text { Diet }\end{array}$ & $\begin{array}{l}+ \\
0\end{array}$ & Simmer et al. 1988 \\
\hline Chile & Mar & $8 \pm 5 \mathrm{~m}$ & $32(M+F)$ & 2 & 3 & $\begin{array}{l}\text { Weight } \\
\text { Diet }\end{array}$ & $\stackrel{+}{0}$ & $\begin{array}{l}\text { Castillo-Duran } \\
\text { et al. } 1987\end{array}$ \\
\hline Chile & Mar & $7 \pm 2 m$ & $39(M+F)$ & 1.9 & 3 & $\begin{array}{l}\text { Length } \\
\text { Diet }\end{array}$ & $\begin{array}{l}+^{r} \\
0\end{array}$ & $\begin{array}{l}\text { Schlesinger } \\
\text { et al. } 1992\end{array}$ \\
\hline Jamaica & Mal & $4-31 \mathrm{~m}$ & $12 \mathrm{M}, 4 \mathrm{~F}$ & $1 \cdot 6-6.4$ & 1 & Weight & + & $\begin{array}{l}\text { Golden \& Golden } \\
1981\end{array}$ \\
\hline Jamaica & Mal & $6-31 \mathrm{~m}$ & $11 \mathrm{M}$ & $5-10^{d}$ & 1.5 & $\begin{array}{l}\text { Diet } \\
\text { Weight }\end{array}$ & $\begin{array}{l}0 \\
0 \\
+\end{array}$ & $\begin{array}{l}\text { Golden \& Golden } \\
1992\end{array}$ \\
\hline Kenya & $\mathrm{Kwa}^{\mathrm{e}}$ & $1-3 y$ & $58(M+F)$ & 5 & 0.3 & $\begin{array}{l}\text { N metabolism } \\
\text { Weight }\end{array}$ & $\begin{array}{l}+ \\
+\end{array}$ & $\begin{array}{l}\text { Gatheru et al. } \\
1988\end{array}$ \\
\hline
\end{tabular}

Mal, mixed marasmus, kwashiorkor, marasmic-kwashiorkor; Mar, marasmus; Kwa, kwashiorkor. The zinc dose was added to the rehabilitation diet, except where stated.

+ , Significant effect of supplement; 0 , no effect.

" Zinc dose given per $\mathrm{kg}$ body weight per day.

b Home diet supplemented with vitamins.

" Advantage in length gain seen at $30 \mathrm{~d}$ only.

d Dose given per kg feed.

e Children given a high protein diet.

pronounced growth faltering or low plasma/hair $\mathrm{Zn}$ levels. Whether the effects of $\mathrm{Zn}$ are a direct consequence of improving $\mathrm{Zn}$ supply for tissue growth and metabolism or are mediated through stimulation of the appetite is unclear.

The results of $\mathrm{Zn}$ supplementation are more dramatic for children, male and female, recovering from severe malnutrition when growth is extremely rapid and requirements are much greater than normal (Table 7). $\mathrm{Zn}$ supplementation of customary rehabilitation diets not only improves weight gain but produces proportionately greater deposition of lean tissue (Golden \& Golden, 1992). An increase in length gain was noted in one study (Schlesinger et al. 1992). In addition, $\mathrm{Zn}$ treatment of young children recovering from severe diarrhoea has been shown to enhance length gains (Behrens et al. 1990).

The main impression from the few available Ca studies is that supplementation with $\mathrm{Ca}$ alone or together with $\mathbf{P}$ has little impact on rate of growth but may correct biochemical indicators of marginal Ca status (Table 8). Exceptions are the studies of Indian children by Aykroyd \& Krishnan $(1938,1939)$ in which significant differences in height and weight gain over 3-5 months were observed between control children and those supplemented with relatively low doses of $\mathrm{Ca}$. The differences in height gain were small (3-6 years: 0.14 inches; 6-12 years: 0.21 inches). It has been speculated that the results could be explained by stimulation of the appetite by the calcium salt with consequent increases in food intake (Walker, 1954).

In addition to controlled studies with calcium salts there have been a number of investigations in which calcium-rich or calcium-enriched foods have been provided. For example, improved growth after supplementation with animal milks and with $\mathrm{Ca}$-enriched dhokla (fermented batter) have been reported (Aykroyd et al. 1937; Aykroyd \& Krishnan, 1939; Rajalakshmi et al. 1973; Vaughan et al. 1981). These studies are difficult to interpret 
Table 8. Controlled calcium supplementation studies in children from developing countries with low to medium calcium intakes

\begin{tabular}{|c|c|c|c|c|c|c|c|c|}
\hline & & Age & Number & $\begin{array}{c}\text { Calcium } \\
\text { dose }^{\mathrm{a}} \\
(\mathrm{mg} / \mathrm{d})\end{array}$ & $\begin{array}{c}\text { Suppl. } \\
\text { time } \\
\text { (months) }\end{array}$ & Outcome & & Reference \\
\hline India & $\begin{array}{l}\text { Mid SE } \\
\text { school }\end{array}$ & $3-6 y$ & $87(M+F)$ & $65 \mathrm{mg}^{\mathrm{h}}$ & $4-5$ & $\begin{array}{l}\text { Height } \\
\text { Weight }\end{array}$ & $\begin{array}{l}+ \\
+\end{array}$ & 1 \\
\hline India & Low SE & $6-12 y$ & $100(M+F)$ & $130 \mathrm{mg}^{\mathrm{b}}$ & 3 & $\begin{array}{l}\text { Height } \\
\text { Weight }\end{array}$ & $\begin{array}{l}+ \\
+\end{array}$ & 2 \\
\hline India & Low SE & $6-30 \mathrm{~m}$ & $14 \mathrm{M}, 24 \mathrm{~F}$ & $\begin{array}{l}410^{\circ} \\
820^{r}\end{array}$ & 10 & $\begin{array}{l}\text { Length } \\
\text { Weight } \\
\text { Anthrops } \\
\text { Bone }^{\text {d }}\end{array}$ & $\begin{array}{l}0 \\
0 \\
0 \\
0\end{array}$ & 3 \\
\hline $\begin{array}{l}\text { South } \\
\text { Africa }\end{array}$ & $\begin{array}{l}\text { Urban } \\
\text { School }\end{array}$ & $6-14 y$ & $179(\mathrm{M}+\mathrm{F})$ & $454^{\prime}$ & 36 & $\begin{array}{l}\text { Height } \\
\text { Weight }\end{array}$ & $\begin{array}{l}0 \\
0\end{array}$ & 4 \\
\hline $\begin{array}{l}\text { South } \\
\text { Africa }\end{array}$ & Low SE & $9-12 y$ & $60(M+F)$ & $500^{8}$ & 3 & $\begin{array}{l}\text { Height } \\
\text { Weight } \\
\text { Biochem }\end{array}$ & $\begin{array}{l}0 \\
-h \\
+^{1}\end{array}$ & 5 \\
\hline Surinam & $\begin{array}{l}\text { Mid SE } \\
\text { School }\end{array}$ & $6-12 y$ & $85 \mathrm{M}$ & $400^{\mathrm{b}}$ & 15 & $\begin{array}{l}\text { Height } \\
\text { Weight } \\
\text { Anthrops } \\
\text { Bone }^{\mathrm{d}}\end{array}$ & $\begin{array}{l}0 \\
0 \\
0 \\
0\end{array}$ & 6 \\
\hline
\end{tabular}

mg elemental Ca given.

b Given as calcium lactate (130 mg Ca/g).

C Children younger and older than one year received 2.5 and $5 \mathrm{~g}$ calcium glycerophosphate $(191 \mathrm{mg} \mathrm{Ca} / \mathrm{g}$, $140 \mathrm{mg} \mathrm{P} / \mathrm{g}$ ) respectively 6 days a week

¿ Other anthropometric indices.

- Bone, appearance of ossification centres; radiographic bone dimensions.

' $500 \mathrm{mg} \mathrm{Ca}, 500 \mathrm{mg} \mathrm{P}$ as calcium carbonate-dicalcium phosphate for 3 years corrected for 100 days of school vacation.

B Calcium Sandoz Forte (mainly calcium lactate-gluconate).

" Placebo group weighed significantly more at end of study.

i Supplementation caused significant biochemical differences (serum calcium, phosphorus, alkaline phosphatase ; urinary calcium, phosphorus) relative to the placebo group.

References are:

1. Aykroyd \& Krishnan, 1938, 2. Aykroyd \& Krishnan, 1939, 3. Bansal et al 1964, 4. Malan \& Ockerse, 1941, 5. Pettifor et al. 1981 b, 6. Luyken et al. 1967.

in terms of an improved $\mathrm{Ca}$ supply as the results probably reflect increases in total food intakes rather than the correction of a putative Ca deficiency.

\section{CONCLUSIONS}

The available evidence relating linear growth retardation in developing countries to dietary mineral supply can be summarized as follows:

1. The average $\mathbf{P}$ and $\mathrm{Mg}$ intakes of children in developing countries are substantially greater than biological requirements (accretion + losses). In addition, there is evidence that absorption of these minerals and conservation of endogenous losses are likely to be high. It would appear unlikely, therefore, that an inadequate dietary supply of $\mathrm{P}$ or $\mathrm{Mg}$ contributes to the poor linear growth of Third World children.

2. $\mathrm{Zn}$ intakes of breast fed children are close to the biological requirement, if one assumes that there is only limited capacity to reduce losses. Children who are no longer breast fed have intakes that are 4-5 times above the biological requirement but $\mathrm{Zn}$ supply 
may be restricted by poor bioavailability. Supplementation studies suggest that the linear growth of vulnerable groups of children, particularly infant and adolescent boys, can be increased by raising $\mathrm{Zn}$ intakes. The mechanism by which this occurs is unknown but may be related to stimulation of appetite or to metabolic effects, rather than to an improved supply of $\mathrm{Zn}$ for bone formation per se.

3. Ca intakes are close to the biological requirement for children of all ages in many developing countries ( $<1-2$ times). In addition, absorption of $\mathrm{Ca}$ from Third World diets may be poor. There is little information about the extent to which children can adapt to low $\mathrm{Ca}$ intakes in terms of enhanced absorption and decreased losses but it must be assumed that substantial adaptation can occur. It may be that slow growth rates represent an adaptation to limited mineral supply. There are indications that marginal Ca status may be reflected in biochemical signs of hyperparathyroidism and in low bone mineral contents, and may induce or predispose children to rickets. The evidence from the small number of $\mathrm{Ca}$ supplementation studies on the effects of increasing $\mathrm{Ca}$ intakes on bone growth and development is inconclusive.

In conclusion, this review suggests that more research is warranted into the link between human bone growth and development and dietary $\mathrm{Ca}$ and $\mathrm{Zn}$ supply, but that $\mathrm{P}$ and $\mathrm{Mg}$ intakes are unlikely to be important in the aetiology of stunting. In reaching these conclusions a number of assumptions have had to be made which should be borne in mind. First, the wide differences there are likely to be in requirements, intakes and ability to adapt between individual children have not been considered. Secondly, estimating needs on the basis of mineral deposition rates does not take account of the intakes which may be required to maintain optimal function, especially relevant for $\mathrm{Zn}$ and $\mathrm{Mg}$. Thirdly, the arguments are based on inadequate data, particularly with respect to the mineral content of the body, the absorption and losses of minerals from children habituated to low intakes, and the identification of marginal mineral status in Third World children. It is to be hoped that more information will become available in the future with the advent of new sensitive, non-invasive techniques, such as stable isotope techniques for measuring absorption and absorptiometric methods for assessing bone mass, and as a result of the current search for specific markers of marginal mineral status and of bone turnover.

\section{REFERENCES}

Adams, P. \& Berridge, F. R. (1969). Effects of kwashiorkor on cortical and trabecular bone. Archives of Disease in Childhood 44, 705-709.

Aggett, P. J. (1988). Severe zinc deficiency. In Zinc in Human Biology, pp. 259-279 [C. F. Mills, editor]. Berlin: Springer-Verlag.

Allen, L. H. (1982). Calcium bioavailability and absorption: a review. American Journal of Clinical Nutrition 35 , 783-808.

Anderson. B. M.. Gibson, R. S. \& Sabry, J. H. (1981). The iron and zinc status of long-term vegetarian women. American Journal of Clinical Nutrition 34, 10421048.

Anderson, M. P., Hunt, R. D., Griffiths, H. J., Mclntyre. K. W. \& Zimmerman, R. E. (1977). Long-term effect of low dietary calcium: phosphate ratio on the skeleton of Cebus albifrons monkeys. Journal of Nutrition 107. $834-839$.

Aykroyd, W. R. \& Krishnan, B. G. (1938). Effect of calcium lactate on children in a nursery school. Lancet ii. $153-155$.

Aykroyd, W. R. \& Krishnan, B. G. (1939). A further experiment on the value of calcium lactate for Indian children. Indian Journal of Medical Research 27, 409-412.

Aykroyd, W. R., Krishnan, B. G. \& Madhava, K. B. (1937). The effect of skimmed milk, soya bean, and other foods in supplementing typical Indian diets. Indian Journal of Medical Research 24, 1093-1115.

Bansal. P., Rau, P., Venkatachalam, P. S. \& Gopalan, C. (1964). Effect of calcium supplementation on children in a rural community. Indian Journal of Medical Research 52, 219-223.

Bates, C. J., Evans, P. H., Dardenne, M., Prentice, A., Lunn, P. G., Northrop-Clewes, C. A., Hoare, S., Cole, T. J., Horan, S. J., Longman, S. C., Stirling, D. \& Aggett, P. J. (1993). A trial of zinc supplementation in young rural Gambian children. British Journal of Nutrition 69, 243-255. 
Bates, C. J. \& Tsuchiya, H. (1990). Zinc in breast milk during prolonged lactation: comparison between the UK and The Gambia. European Journal of Clinical Nutrition 44.61-69.

Begum, A. \& Pereira, S. M. (1969). Calcium balance studies on children accustomed to low calcium intakes. British Journal of Nutrition 23, 905-911.

Behrens, R. H., Tomkins, A. M. \& Roy, S. K. (1990). Zinc supplementation during diarrhoea, a fortification against malnutrition? Lancet 336, 442-443.

Bhaskaram, C. \& Reddy, V. (1979). Role of dietary phytate in the aetiology of nutritional rickets. Indian Journal of Medical Research 69, 265-270.

Bindra, G. S., Gibson, R. S. \& Thompson, L. U. (1986). [Phytate]/[calcium]/[zinc] ratios in Asian immigrant lactovo vegetarian diets and their relationship to zinc nutriture. Nutrition Research 6, 475-483.

Bishop, N. (1989). Bone disease in preterm infants. Archives of Disease in Childhood 64, 1403-1409.

British Nutrition Foundation. (1989). Calcium. London: The British Nutrition Foundation.

Bronner, F., Harris, R. S., Maletskos, C. J. \& Benda, C. E. (1954). Studies in calcium metabolism. Effect of food phytates on calcium ${ }^{45}$ uptake in children on low-calcium breakfasts. Journal of Nutrition 54, 523-542.

Bronner, F., Harris, R. S., Maletskos, C. J. \& Benda, C. E. (1956). Studies in calcium metabolism. Effect of food phytates on calcium ${ }^{45}$ uptake in boys on a moderate calcium breakfast. Journal of Nutrition 59, $393-406$.

Carter, J. P., Grivetti, L. E., Davis, J. T., Nasiff, S., Mansour, A., Mousa, W. A., Atta, A., Patwardhan, V. N., Abdel Moneim, M., Abdou, I. A. \& Darby, W. J. (1969). Growth and sexual development of adolescent Egyptian village boys. Effects of zinc, iron and placebo supplementation. American Journal of Clinical Nutrition 22, 59-78.

Castillo-Duran, C., Heresi, G., Fisberg, M. \& Uauy, R. (1987). Controlled trial of zinc supplementation during recovery from malnutrition: effects on growth and immune function. American Journal of Clinical Nutrition 45 , $602-608$.

Cerqueira, M. T., McMurry Fry, M. \& Connor, W. E. (1979). The food and nutrient intakes of the Tarahumara Indians of Mexico. American Journal of Clinical Nutrition 32, 905-915.

Chase, H. P., Hambidge, K. M., Barnett. S. E., Houts-Jacobs, M. J., Lenz, K. \& Gillespie, J. (1980). Low vitamin A and zinc concentrations in Mexican-American migrant children with growth retardation. American Journal of Clinical Nutrition 33, 2346-2349.

Chen, X.-C., Yin, T.-A., He, J.-S., Ma, Q.-Y., Han, Z.-M. \& Li, L.-X. (1985). Low levels of zinc in hair and blood, pica, anorexia and poor growth in Chinese preschool children. American Journal of Clinical Nutrition 42. $694-700$.

Chusilp, K., Somnasang, P., Kirdpon, W., Wongkham, S., Sribonlue, P., Mahaverawat, U., Yongvanit, P., Sawakontha, S. \& Waterlow, J. (1992). Observations on the development of stunting in children of the Khon Kaen region of Thailand. European Journal of Clinical Nutrition 46, 475-487.

Clements, M. R., Johnson, L. \& Fraser, D. R. (1987). A new mechanism for induced vitamin D deficiency in calcium deprivation. Nature 325, $62 \cdot 65$.

Cohn, S. H., Abesamis, C., Zanzi, I., Aloia, J. F., Yasumura, S. \& Ellis, K. J. (1977). Body elemental composition: comparison between black and white adults. American Journal of Physiolog. 232, E419-E422.

Creed de Kanashiro, H., Brown, K. H., Lopez de Romaña, G., Lopez, T. \& Black, R. E. (1990). Consumption of food and nutrients by infants in Huascar (Lima), Peru. American Journal of Clinical Nutrition 52, 995-1004.

Dagnelie, P. C., Vergote, F. J. V. R. A., van Staveren, W. A., van den Berg, H., Dingjan, P. G. \& Hautvast, J. G. A. J. (1990). High prevalence of rickets in infants on macrobiotic diets. American Journal of Clinical Nutrition 51, 202-208.

Department of Health (1989). The Diets of British Schoolchildren (Report on Health and Social Subjects No. 36). London: Her Majesty's Stationery Office.

Department of Health (1991). Dietary Reference Values for Food Energy and Nutrients for the United Kingdom (Report on Health and Social Subjects No. 41). London: Her Majesty's Stationery Office.

Dirren, H., Barclay, D., Gil Ramos, J., Montalvo, M.-M. \& Lozano, R. (1993). Zinc supplementation and infant growth in Ecuador. In Nutrient Regulation during Pregnancy, Lactation and Infant Growth. New York: Plenum Press (In the press)

Eyberg. C. J., Pettifor, J. M. \& Moodley, G. (1986). Dietary calcium intake in rural black South African children. The relationship between calcium intake and calcium nutritional status. Human Nutrition: Clinical Nutrition 40C, 69-74.

Ferguson, E. L., Gibson, R. S., Thompson, L. U. \& Ounpuu, S. (1989). Dietary calcium, phytate, and zinc intakes and the calcium, phytate, and zinc molar ratios of the diets of a selected group of East African children. American Journal of Clinical Nutrition 50. 1450-1456.

Fomon, S. J. (1974). Infant Nutrition, 2nd edn. Philadelphia, PA: W. B. Saunders.

Fraser, D. R. (1988a). Bone minerals and fat-soluble vitamins. In Comparative Nutrition, pp. 105-116 [K. Blaxter and I. Macdonald, editors]. London: John Libbey.

Fraser, D. R. (1988b). Nutritional growth retardation: experimental studics with special reference to calcium. In Linear Growth Retardation in Less Developed Countries (Nestlé Nutrition Workshop Series Vol. 14), pp. 127-141 [J. C. Waterlow, editor]. New York: Raven Press.

Fraser, D. R. (1991). Physiology of vitamin D and calcium homeostasis. In Rickets (Nestle Nutrition Workshop Series Vol. 21), pp 23-34 [F. H. Glorieux, editor]. New York: Raven Press. 
Garn, S. M., Rohmann, C. G., Behar, M., Viteri, F. \& Guzman, M. A. (1964). Compact bone deficiency in protein-caloric malnutrition. Science 145, 1444-1445.

Gatheru, Z., Kinoti, S., Alwar, J. \& Mwita, M. (1988). Serum zinc levels in children with kwashiorkor aged one to three years at Kenyatta National Hospital and the effect of zinc supplementation during recovery. East African Medical Journal 65, 670-679.

Gibson, R. S., Heywood, A., Yaman, C., Sohlström, A., Thompson, L. U. \& Heywood, P. (1991). Growth in children from the Wosera subdistrict. Papua New Guinea, in relation to energy and protein intakes and zinc status. American Journal of Clinical Nutrition 53, 782-789.

Gibson, R. S., Vanderkooy, P. D. S., MacDonald, A. C., Goldman, A., Ryan, B. A. \& Berry, M. (1989). A growth-limiting, mild zinc-deficiency syndrome in some Southern Ontario boys with low height percentiles. American Journal of Clinical Nutrition 49, 1266-1273.

Golden, B. E. \& Golden, M. H. N. (1979). Plasma zinc and the clinical features of malnutrition. American Journal of Clinical Nutrition 32, 2490-2494.

Golden, M. H. N. \& Golden, B. E. (1981). Effect of zinc supplementation on the dietary intake, rate of weight gain, and energy cost of tissue deposition in children recovering from severe malnutrition. American Journal of Clinical Nutrition 34, 900-908.

Golden, B. E. \& Golden, M. H. N. (1992). Effect of zinc on lean tissue synthesis during recovery from malnutrition. European Journal of Clinical Nutrition 46, 697-706.

Golden, M. H. N. (1988). The role of individual nutrient deficiencies in growth retardation of children as exemplified by zinc and protein. In Linear Growth Retardation in Less Developed Countries (Nestle Nutrition Workshop Series Vol. 14), pp. 143-163 [J. C. Waterlow, editor]. New York: Raven Press.

Golden, M. H. N., Golden, B. E., Harland, P. S. E. G. \& Jackson. A. A. (1978). Zinc and immunocompetence in protein-energy malnutrition. Lancet i, 1226-1227.

Golub, M. S., Gershwin, M. E., Hurley, L. S., Saito, W. Y. \& Hendrickx, A. G. (1984). Studies of marginal zinc deprivation in rhesus monkeys. IV. Growth of infants in the first year. American Journal of Clinical Nutrition 40, 1192-1202.

Hambidge, K. M., Casey, C. E. \& Krebs, N. F. (1986). Zinc. In Trace Elements in Human and Animal Nutrition, Vol. 2, pp. $1-137$ [W. Mertz, editor]. New York: Academic Press.

Hambidge, K. M., Chavez, M. N., Brown, R. M. \& Walravens, P. A. (1979). Zinc nutritional status of young middle-income children and effects of consuming zinc-fortified breakfast cereals. American Journal of Clinical Nutrition 32, 2532-2539.

Hegsted, D. M., Moscoso, I. \& Collazos, C. (1952). A study of the minimum calcium requirements of adult men. Journal of Nutrition 46, 181-201.

Irving. J. T. (1964). Dynamics and function of phosphorus. In Mineral Metabolism, Vol. 2 A, pp. 249-313 [C. L. Comar and F. Bronner, editors]. New York: Academic Press.

Kanis, J. A. \& Passmore, R. (1989). Calcium supplementation of the diet. I. British Medical Journal 298, 137-140

Keller, W. (1988). The epidemiology of stunting. In Linear Growth Retardation in Less Developed Countries (Nestlé Nutrition Workshop Series Vol. 14), pp. 17-39 [J. C. Waterlow, editor]. New York: Raven Press.

King, J. C. \& Turnlund, J. R. (1988). Human zinc requirements. In Zinc in Human Biology, pp. 335-350 [C. F. Mills, editor]. Berlin: Springer-Verlag.

Kooh, S. W., Fraser, D., Reilly, B. J., Hamilton, J. R., Gall, D. G. \& Bell, L. (1977). Rickets due to calcium deficiency. New England Journal of Medicine 297, 1264-1266.

Krebs, N. F. \& Hambidge, K. M. (1986). Zinc requirements and zinc intakes of breast-fed infants. American Journal of Clinical Nutrition 43, 288-292.

Krebs, N. F., Hambidge, K. M., Jacobs, M. A. \& Rasbach, J. O. (1985). The effects of a dietary zinc supplement during lactation on longitudinal changes in maternal zinc status and milk zinc concentrations. American Journal of Clinical Nutrition 41, 560-570.

Krebs, N. F., Hambidge, K. M. \& Walravens, P. A. (1984). Increased food intake of young children receiving a zinc supplement. American Journal of Diseases of Children 138, 270-273.

Laskey, M. A., Dibba, B. \& Prentice, A. (1991). Low ratios of calcium to phosphorus in the breast-milk of rural Gambian mothers. Acta Paediatrica Scandinavica 80, 250-251.

Laskey, M. A., Prentice, A., Shaw. J., Zachou, T. \& Ceesay, S. M. (1990). Breast-milk calcium concentrations during prolonged lactation in British and rural Gambian mothers. Acta Paediatrica Scandinavica 79, 507-512.

Lawson. D. E. M., Cole, T. J., Salem, S. I., Galal, O. M., El-Meligy, R., Abdel-Azim, S., Paul, A. A. \& ElHusseini, S. (1987). Actiology of rickets in Egyptian children. Human Nutrition: Clinical Nutrition 41 C, 199- 208.

Leek, J. C., Vogler, J. B., Gershwin, M. E., Golub, M. S., Hurley, L. S. \& Hendrickx, A. G. (1984). Studies of marginal zinc deprivation in rhesus monkeys. V. Fetal and infant skeletal effects. American Journal of Clinical Nutrition 40, $1203-1212$.

Leek, J. C., Keen, C. L., Vogler, J. B., Golub, M. S., Hurley, L. S., Hendrickx, A. G. \& Gershwin, M. E. (1988). Long-term marginal zinc deprivation in rhesus monkeys. IV. Effects on skeletal growth and mineralization. American Journal of Clinical Nutrition 47, 889-895.

Leitch, I. \& Aitken, F. C. (1959). The estimation of calcium requirement: a re-examination. Nutrition Abstracts and Reviews 29, 393-411. 
Linhares, E. D. R., Round, J. M. \& Jones, D. A. (1986). Growth, bone maturation, and biochemical changes in Brazilian children from two different socioeconomic groups. American Journal of Clinical Nutrition 44, $552-558$.

Lo, C., Jarjou, L., Poppitt. S., Cole, T. J. \& Prentice, A. (1990). Delayed development of peak bone mass in West African adolescents. In Osteoporosis 1990, Vol 1, pp. 73-77 [C. Christiansen and K. Overgaard, editors]. Aalborg, Denmark: Handelstrykkeriet Aalborg Aps.

Luyken, R. \& Luyken-Koning, F. W. M. (1961). Studies on the physiology of nutrition in Surinam. VIII. Metabolism of calcium. Tropical and Geographical Medicine 13, 46-54.

Luyken, R. \& Luyken-Koning, F. W. M. (1969). Studies on physiology of nutrition in Surinam. XII. Nutrition and development of muscular, skeletal, and adipose tissues in Surinam children. American Journal of Climical Nutrition 22, 519-526.

Luyken, R., Luyken-Koning, F. W. M., Cambridge, T. H., Dohle, T. \& Bosch, R. (1967). Studies on physiology of nutrition in Surinam. X. Protein metabolism and influence of extra calcium on the growth of and calcium metabolism in boarding school children. American Journal of Clinical Nutrition 20, 34-42.

Malan, A. I. \& Ockerse, T. (1941). The effect of the calcium and phosphorus intake of school children upon dental caries, body weights and heights. South African Dental Journal 15, 153-158.

Maltz, H. E., Fish, M. B. \& Holliday, M. A. (1970). Calcium deficiency rickets and the renal response to calcium infusion. Pediatrics 46. 865870.

Marie, P. J., Pettifor, J. M., Ross, F. P. \& Gloricux, F. H. (1982). Histological osteomalacia due to dietary calcium deficiency in children. New England Journal of Medicine 307, 584-588.

Mitchell, H. H., Hamilton. T. S., Steggerda, F. R. \& Bean, H. W. (1945). The chemical composition of the adult human body and its bearing on the biochemistry of growth. Journal of Biological Chemistry 158, 625637.

Moore, T. Impey, S. G., Martin, P. E. N. \& Symonds, K. R. (1963). Meat diets. II. Effect of the age of rats on their ability to withstand the low calcium intake induced by a diet of minced beef. Journal of Nutrition 80 , 162-170.

Murphy, S. P., Beaton. G. H. \& Calloway, D. H. (1992). Estimated mineral intakes of toddlers: predicted prevalence of inadequacy in village populations in Egypt, Kenya, and Mexico. American Journal of Clinical Nutrition 56, 565-572.

Nicholls, L. \& Nimalasuriya, A. (1939). Adaptation to a low calcium intake in reference to the calcium requirements of a tropical population. Journal of Nutrition 18, 563-577

O'Dell, B. L. \& Reeves, P. O. (1988). Zinc status and food intake. In Zinc in Human Biology, pp. 173-181 [C. F. Mills, editor]. Berlin: Springer-Verlag.

Oppé, T. E. \& Redstone, D. (1968). Calcium and phosphorus levels in healthy newborn infants given various types of milk. Lancet i, 1045-1048.

Ornoy, A.. Wolinsky, I. \& Guggenheim, K. (1974). Structure of long bones of rats and mice fed a low calcium diet. Calcified Tissue Research 15, 71-76.

Pettifor, J. M. (1991). Dietary calcium deficiency. In Rickets (Nestle Nutrition Workshop Series Vol. 21), pp. 123-143 [F. H. Glorieux, editor]. New York: Raven Press.

Pettifor, J. M., Marie, P. J., Sly, M. R., du Bruyn, D. B., Ross, F., Isdale, J. M., de Klerk, W. A. \& van der Walt, W. H. (1984). The effect of differing dietary calcium and phosphorus contents on mineral metabolism and bone histomorphometry in young vitamin D-replete baboons. Calcified Tissue International 36, 668-676.

Pettifor, J. M., Ross, P.. Moodley, G. \& Shuenyane, E. (1979). Calcium deficiency in rural black children in South Africa a comparison between rural and urban communities. American Journal of Clinical Nutrition 32, $2477-2483$.

Pettifor, J. M., Ross, P., Moodley, G. \& Shuenyane, E. (1981 b). The effect of dictary calcium supplementation on serum calcium, phosphorus, and alkaline phosphatase concentrations in a rural black population. American Journal of Clinical Nutrition 34, 2187-2191.

Pettifor, J. M., Ross, P., Travers, R., Glorieux. F. H. \& Deluca, H. F. (1981 a). Dietary calcium deficiency: a syndrome associated with bone deformities and elevated serum 1,25-dihydroxyvitamin D concentrations. Metabolic Bone Diseases and Related Research 2, 301-305.

Pettifor, J. M., Ross, P., Wang, J., Moodley, G. \& Couper-Smith, J. (1978). Rickets in children of rural origin in South Africa: is low dietary calcium a factor? Journal of Pediatrics 92, $320-324$.

Prentice, A. (1991). Functional significance of marginal calcium deficiency. In Modern Lifestyles, Lower Energy' Intake and Micronutrient Status, pp. 139-154 [K. Peitrzik, editor]. London: Springer-Verlag.

Prentice, A., Laskey. M. A., Shaw. J., Cole, T. J. \& Fraser, D. R. (1990). Bone mineral content of Gambian and British children aged 0-36 months. Bone and Mineral 10, 211224.

Prentice, A.. Laskey, M. A., Shaw, J., Hudson, G., Day, K., Jarjou, L. M. A., Dibba, B. \& Paul, A. A. (1993). The calcium and phosphorus intakes of rural Gambian women during pregnancy and lactation. British Journal of Nutrition 69. 885-896.

Prentice, A. \& Paul, A. (1990). Contribution of breast-milk to nutrition during prolonged breast-feeding. In Human Lactation. 4. Breast-feeding, Nutrition, Infections and Infant Growth, pp. 87-102 [S. Atkinson. L. Hanson and R. Chandra, editors]. St John's: ARTS Biomedical Publishers.

Prentice, A. M., Paul, A. A., Prentice, A.. Black, A. E., Cole, T. J. \& Whitehead, R. G. (1986). Cross-cultural differences in lactational performance. In Human Lactation. 2. Maternal and Environmental Factors, pp. $13-44$ [M. Hamosh and A. S. Goldman, editors]. New York: Plenum Press. 
Rajalakshmi, R., Sail, S. S., Shah, D. G. \& Ambady, S. K. (1973). The effects of supplements varying in carotene and calcium content on the physical, biochemical and skeletal status of preschool children. British Journal of Nutrition 30, 77-86.

Ronaghy, H., Reinhold, J. G., Mahloudji, M., Ghavami, P., Spivey Fox, M. R. \& Halsted, J. A. (1974). Zinc supplementation of malnourished schoolboys in Iran: increased growth and other effects. American Journal of Clinical Nutrition 27, 112-121.

Ronaghy, H., Spivey Fox, M. R., Garn, S. M., Israel, H., Harp, A., Moe, P. G. \& Halsted, J. A. (1969). Controlled zinc supplementation for malnourished school boys: a pilot experiment. American Journal of Clinical Nutrition 22, 1279-1289.

Russell, R. G. G., Caswell, A. M., Hearn, P. R. \& Sharrard, R. M. (1986). Calcium in mineralized tissues and pathological calcification. British Medical Bulletin 42, 435-446.

Sandstead, H. H. (1985). Requirement of zinc in human subjects. Journal of the American College of Nutrition 4 , 73-82.

Sandstead, H. H. (1991). Zinc deficiency. A public health problem? American Journal of Diseases of Children 145, 853-859.

Sandström, B., Cederblad, Å., Kivistö, B., Stenquist, B. \& Andersson, H. (1986). Retention of zinc and calcium from the human colon. American Journal of Clinical Nutrition 44, 501-504.

Schlesinger, L., Arevalo, M., Arredondo, S., Diaz, M., Lönnerdal, B. \& Stekel, A. (1992). Effect of a zinc-fortified formula on immunocompetence and growth of malnourished infants. American Journal of Clinical Nutrition 56 , $491-498$.

Schwartz, R. (1990). Magnesium metabolism. In Nutrition and Bone Development, pp. 148-163 [D. J. Simmons, editor]. Oxford: Oxford University Press.

Simmer, K., Khanum, S., Carlsson, L. \& Thompson, R. P. H. (1988). Nutritional rehabilitation in Bangladesh-the importance of zinc. American Journal of Clinical Nutrition 47, 1036-1040.

Smith, R. M., King, R. A., Spargo, R. M., Cheek, D. B., Field, J. B. \& Veitch, L. G. (1985). Growth-retarded aboriginal children with low plasma zinc levels do not show a growth response to supplementary zinc. Lancet i, 923-924.

Solomons, N. W. \& Jacob, R. A. (1981). Studies on the bioavailability of zinc in humans : effects of heme and nonheme iron on the absorption of zinc. American Journal of Clinical Nutrition 34, 475.482.

Specker, B. L. \& Tsang, R. C. (1987). Bone mineralization. Annales Nestle 45, 18-25.

Sundararaj, R., Begum, A., Jesudian, G. \& Pereira, S. M. (1969). Seasonal variation in the diets of pre-school children in a village (North Arcot District). 2. Intake of vitamins and minerals. Indian Journal of Medical Research 57, 375-383.

Taylor, C. M., Bacon, J. R., Aggett, P. J. \& Bremner, I. (1991). Homeostatic regulation of zinc absorption and endogenous losses in zinc-deprived men. American Journal of Clinical Nutrition 53, 755-763.

Udomkesmalee, E., Dhanamitta, S., Yhoung-Aree, J., Rojroongwasinkul, N. \& Smith, J. C. (1990). Biochemical evidence suggestive of suboptimal zinc and vitamin $A$ status in schoolchildren in Northeast Thailand. American Journal of Clinical Nuirition 52, 564-567.

Valyasevi, A. \& Dhanamitta, S. (1967). Studies of bladder stone disease in Thailand. VIl. Urinary studies in newborn and infants of hypo- and hyper-endemic areas. American Journal of Clinical Nutrition 20, $1369-1377$.

Valyasevi, A., Dhanamitta, S. \& Van Reen, R. (1969). Studies of bladder stone disease in Thailand. X. Effect of orthophosphate and nonfat dry milk supplementations on urine composition. American Journal of Clinical Nutrition 22, 218-227.

Valyasevi, A., Halstead, S. B., Pantuwatana, S. \& Tankayul, C. (1967). Studies of bladder stone disease in Thailand. IV. Dietary habits, nutritional intake, and infant feeding practices among residents of a hypo- and hyper-endemic area. American Journal of Clinical Nutrition 20, 13401351.

Vaughan, J. P., Zumrawi, F., Waterlow, J. C. \& Kirkwood, B. R. (1981). An evaluation of dried skimmed milk on children's growth in Khartoum Province, Sudan. Nutrition Research 1, 243-252.

Wacker, W. E. C. \& Vallee, B. L. (1964). Magnesium. In Mineral Metabolism, Vol. 2A, pp. 483-521 [C. L. Comar and F. Bronner, editors]. New York: Academic Press.

Walker, A. R. P. (1951). Cereals, phytic acid, and calcification. Lancet 261, 244-248.

Walker, A. R. P. (1954). Does a low intake of calcium retard growth or conduce to stuntedness? American Journal of Clinical Nutrition 2, 265-27l.

Walker, A. R. P. (1972). The human requirement of calcium: should low intakes be supplemented? American Journal of Clinical Nutrition 25, $518 \cdot 530$.

Walker, A. R. P., Fox, F. W. \& Irving, J. T. (1948). Studies in human mineral metabolism. I. The effect of bread rich in phytate phosphorus on the metabolism of certain mineral salts with special reference to calcium. Biochernical Journal 42, 452462.

Walravens, P. A., Chakar, A., Mokni, R., Denise, J. \& Lemonnier, D. (1992). Zinc supplements in breastfed infants. Lancet 340, 683-685.

Walravens, P. A. \& Hambidge, K. M. (1976). Growth of infants fed a zinc supplemented formula. American Journal of Clinical Nutrition 29, 1114-1121.

Walravens, P. A., Hambidge, K. M. \& Koepfer, D. M. (1989). Zinc supplementation in infants with a nutritional pattern of failure to thrive: a double-blind, controlled study. Pediatrics 83, 532-538. 
Walravens, P. A., Krebs, N. F. \& Hambidge, K. M. (1983). Linear growth of low income preschool children receiving a zinc supplement. American Journal of Clinical Nutrition 38, 195201.

Waterlow, J. C. (1988). Observations on the natural history of stunting. In Linear Growth Retardation in Less Developed Countries (Nestlé Nutrition Workshop Series Vol. 14), pp. 1-16 [J. C. Waterlow, editor]. New York: Raven Press.

Widdowson, E. M. \& Dickerson, J. W. T. (1964). Chemical composition of the body. In Mineral Metabolism, Vol. 2A, pp. 1-247 [C. L. Comar and F. Bronner, editors]. New York: Academic Press.

Widdowson, E. M., McCance, R. A., Harrison, G. E. \& Sutton, A. (1963). Effect of giving phosphate supplements to breast-fed babies on absorption and excretion of calcium, strontium, magnesium, and phosphorus. Lancet ii, 12501251.

Xu, P., Price, J., Wise, A. \& Aggett, P. J. (1992). Interaction of inositol phosphates with calcium, zinc, and histidine. Journal of Inorganic Biochemistry, 47, 119-130.

Ziegler, E. E., Serfass, R. E., Nelson, S. E., Figueroa-Colón, R., Edwards, B. B., Houk, R. S. \& Thompson, J. J. (1989). Effect of low zinc intake on absorption and excretion of zinc by infants studied with ${ }^{70} \mathrm{Zn}$ as extrinsic tag. Journal of Nutrition 119, 1647-1653. 